Milena Zorić, univ. dipl, ped.

\title{
EVALVACIJA V IZOBRAŽEVANJU ODRASLIH
}

Pot do večje kakovosti izobraževanja odraslih

\section{POVZETEK}

Priča smo naglemu porastu števila in vrst institucij, ki ponujajo odraslim izobraževanje z različnih področij. Institucije so različno kakovostne, na trgu pa preživijo le tiste, ki se zavedajo. da morajo nenehno vrednotiti svoje delo, tako na institucionalni kot tudi na programski ravni. Avtorica poudari in analizira pomen in vlogo evalvacije institucije in evalvacije programa. Primerja modele evalvacije, ki so se vadnjih desetletjih uveljavili v svetu, z modelom Ponudimo odraslim kakovostno izobraževanje - POKI, ki ga razvijajo v Andragoškem centru Slovenije. $V$ sklepnem delu prispevka poda analizo in kritično oceno tega modela. Sprašuje se, ali je moč model POKI vzpostaviti kot sistem, oziroma kako bi ga bilo potrebno nadgraditi, da bi bilo to mogoče.

Ključne besede: evalvacija, samoevalvacija, kakovost, izobraževanje odraslih

$V_{\text {zadnjih letih je izobraževanje odraslih }}$ dobilo nove razsežnosti. Zaradi družbenih sprememb in posledično večje ponudbe izobraževalnih programov za odrasle imajo ustanove za izobraževanje odraslih poleg

Udeleženci izobraževanja želijo kakovost programov vnaprej preveriti. izobraževalne funkcije tudi funkcijo poslovnega subjekta. To pomeni, da so lahko tudi ustanove za izobraževanje odraslih tržno usmerjene in morajo razvijati konkurenčne prednosti, da bi privabile udeležence, ter iskati dodatne vire financiranja programov na trgu (Kovač, 1997).

Evalvacija izobraževalnih programov in izobraževalnih institucij je pomembna, če želimo doseči kakovost. Vendar se zdi, da sistematična evalvacija $v$ izobraževanju odraslih doslej ni bila pogosta, kar seveda ne pomeni, da ni potrebna, če ne celo nujna. Wolf (1996) navaja kot glavni razlog za evalvacijo in s tem tudi izboljšanje izobraževanja odraslih stroške, ki jih utrpijo udeleženci izobraževanja, ko zanj porabijo čas, ki bi ga sicer lahko uporabili drugače. Udeleženci izobraževalnih programov so namreč pogosto samoplačniki, ki vnaprej plačajo-udeležbo $v$ programu. Zato je razumljiva potreba udeležencev, da poznajo učinkovitost programov, saj $\mathrm{v}$ primeru neučinkovitega programa izgubijo čas in denar.

\section{EVALAVACIJA NA RAVNI INSTITUCIJE IN EVALVACIJA NA RAVNI POSAMEZNIKA}

Evalvacija lahko poteka $v$ izobraževanju odraslih na več ravneh, na ravni programa in 
na ravni institucije. Na kateri ravni bomo izvajali evalvacijo, je odvisno od namenov, ki jih imamo pri tem. Če si želimo preveriti način, kako zagotoviti kakovost, bomo izvedli evalvacijo na ravni institucije. Če pa bo naš namen globje razumeti vsebino in povratne informacije o izobraževalnem programu, bomo izvedli evalvacijo programa (Kump, 2000a). Ali drugače povedano, v evalvaciji programa $\mathrm{v}$ izobraževanju odraslih presojamo, kakšna je učinkovitost izobraževalnih programov in jih na podlagi ugotovitev skušamo izboljšati (Knox, 1989). V evalvacijo programa je potrebno vključiti različne skupine: udeležence izobraževanja, delodajalce, strokovna društva, izobraževalce, vodstyo, administracijo izobraževalnih institucij ipd. Evalvacija institucije pa vključuje evalvacijo programa in postopno prehaja na raven institucije. Namen te evalvacije je ugotoviti, ali ima izobraževalna institucija vzpostavljene mehanizme in postopke za notranjo evalvacijo kakovosti poučevanja, učenja, raziskovanja, vodenja, upravljanja itd. Njena pomanjkljivost se kaže v tem, da ne zagotavlja priporočil za izpopolnjevanje programov, Zato je najbolje evalvacijo institucije dopolnjevati $\mathrm{z}$ evalvacijo programa (Kump, 2000a).

\section{ZUNANJA, NOTRANJA, FORMATIVNA IN SUMATIVNA EVALVACIJA}

Evalvacija se po tem, kdo jo izvaja, deli na zunanjo in notranjo evalvacijo. Zunanjo evalvacijo izvaja evalvator, ki ni iz izobraževalne institucije, kjer se razvije in izvaja program (Macur, 1996), oz. ni član projektne skupine, ki razvija neko programsko novost (Sagadin, 1999). Zunanji evalvator ima neodvisen položaj in prihaja iz vladnih ustanov, različnih neodvisnih inštitutov ali agencij (Kump, 2000b). Notranjo evalvacijo pa izvajajo kar izvajalci programov oz. člani projektne skupine, ki razvijajo programsko novost in opravljajo evalvacijo pri projektu (Sagadin, 1999). Torej dobro poznajo program, ki ga bodo evalvirali.

Glede na to, kdaj se izvaja, se evalvacija deli na formativno in sumativno evalvacijo. Formativna evalvacija se izvaja med potekom izobraževalnega programa $\mathrm{z}$ namenom, da ga izboljša (Možina, 2002). Formativna evalvacija je notranja evalvacija, ki se ukvarja predvsem z izobraževalnim procesom. Namenjena je izboljšanju izobraževalnih dejavnosti. Sumativna evalvacija pa se izvaja ob koncu izobraževalnega programa. Opredeljujemo jo kot zunanjo in končno, saj omogoča, da zberemo večje število posamičnih evalvacij in se na podlagi ugotovitev odločamo o nadaljnji usodi izobraževalnega programa. Ali ga bomo obdržali, izboljšali ali pa se ga bomo odrekli.

\section{EVALVACIJA IZOBRAŽEVANIA ODRASLIH V SLOVENIII}

Da bi v Sloveniji izboljšali kakovost dela organizacij za izobraževanje odraslih, so v Andragoškem centru Slovenije (ACS) razvili model za presojanje in razvijanje kakovosti $\mathrm{v}$ organizacijah za izobraževanje odraslih. Poimenovali so ga model POKI (Ponudimo odraslim kakovostno izobraževanje).

O učinkih vpeljevanja modela POKI v organizacijah za izobraževanje odraslih je bila v študijskem letu 2002/2003 opravljena analiza. Temeljni cilj analize je bil ugotoviti, kakšni so odzivi zaposlenih na model POKI in kako ta vpliva na nadaljnje ugotavljanje

Model POKI ponuja sistematičen način ugotavljanja in zagotavljanja kakovosti na področju izobraževanja odraslih, kar je bilo doslej mnogim izobraževalnim organizacijam v Sloveniji tuje. 


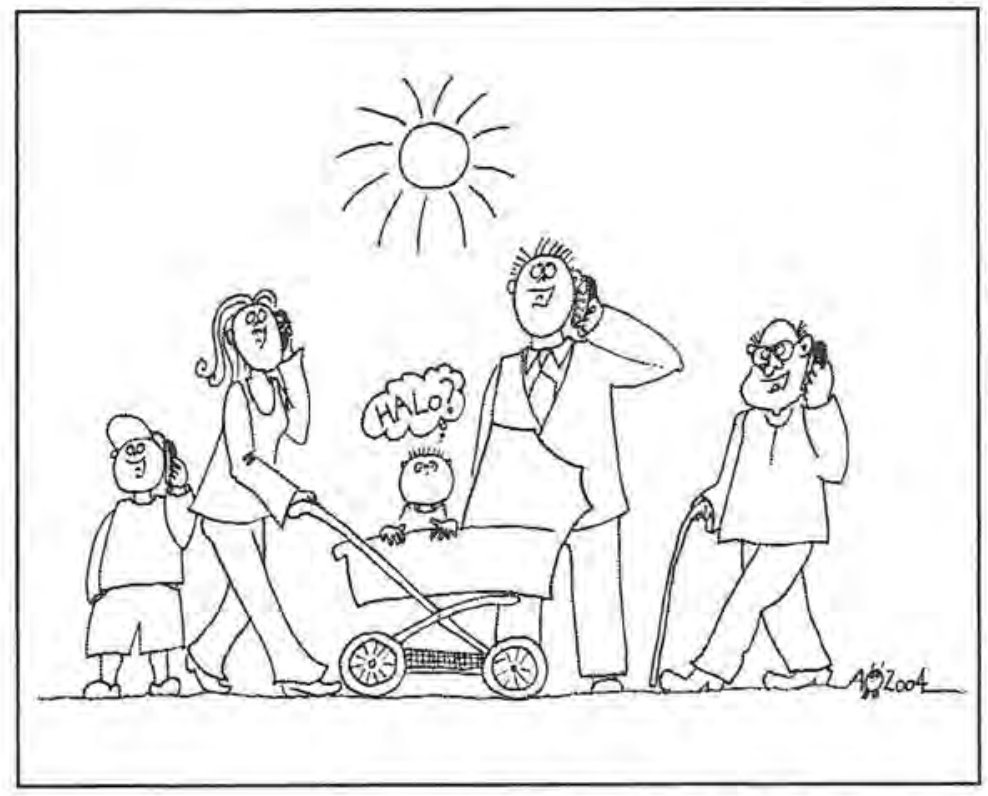

kakovosti izobraževanja odraslih v posamični organizaciji.

\section{METODOLOGIJA}

$\mathrm{V}$ analizo so bile vključene štiri srednje šole, ki so V šolskem letu 2001/2002 začele vpeljevati model POKI. Kot pripomoček za analizo so uporabile anketni vprašalnik in strukturirani intervju. Intervjuji so bili izvedeni ločeno, in sicer s člani samoevalvacijske skupine, ki so sodelovali $\mathrm{v}$ projektu. Na vsaki šoli je bila

Zaposleni predstavljajo pomemben vir evalvacije. vzpostavljena ena samoevalvacijska skupina, v kateri so sodelovali ravnatelj, vodja izobraževanja odraslih in trije, ponekod pa tudi več učiteljev, ki poučujejo odrasle. Tako je vzorec vključeval 22 oseb $(100 \%)$ in lahko rečemo, da je reprezentativen. Anketni vprašalniki so bili posredovani vodjem samoevalvacijskih skupin, ki so jih razdelili učiteljem odraslih. Vsega skupaj je bilo razdeljenih 200 anketnih vprašalnikov, od tega je bilo vrnjenih $67(33,5 \%)$, ki so bili vključeni $v$ obdelavo podatkov. Na podlagi tega vzorca rezultatov ni bilo moč posploševati, saj vzorec ni reprezentativen (Zorić, 2003).

\section{SAMOEVALVACIJSKI PROCESI V MODELU POKI IN DRUGIH MODELIH}

Model POKI temelji na metodi notranje evalvacije, tj. na samoevalvaciji, s pomočjo katere izobraževalne organizacije same pridobijo podatke o kakovosti svojega dela, ki ga žclijo izboljšati. Samoevalvacijo izvajajo zaposleni v organizaciji, in sicer predavatelji, organizatorji izobraževanja odraslih, vodstvo, administracija ipd. Prav zato je to ena izmed najprimernejših metod za ugotavljanje kakovosti dela izobraževalnih organizacij in programov, saj ostanejo podatki znotraj organizacije. Zunanjih sankcij ni. Pri tem pa je zelo pomembno, da vodstvo podpre samoevalvacijske aktivnosti in zagotovi vsem zaposlenim, da $v$ primeru ugotovljenih slabosti njihovega dela ne bo sledilo kaznovanje (Musek-Lešnik, 2001). To je bilo ugotovljeno tudi $v$ analizi samoevalvacijskih procesov $v$ modelu POKI (Zorić, 2003), saj v neki instituciji, zajeti $\mathrm{v}$ analizo, zaposleni niso hoteli sodelovati pri ugotavljanju slabosti njihovega dela, ker vodstvo na začetku ni vidno podpiralo takšnih samoevalvacijskih aktivnosti $v$ njihovi organizaciji.

V strokovni literaturi (Kump, 1995, Medveš, 2000, Musek-Lešnik, 2001) o samoevalvaciji najdemo trditev, da je najustreznejša rešitev vzpostavitev samoevalvacijske skupine, ki naj ugotovi stanje v organizaciji. Njeni člani naj bi bile tiste osebe, ki jim zaposleni $v$ organizaciji zaupajo. Da bi se to zaupanje ohranilo ves čas poteka samoevalvacije, morajo biti vsi udeleženci samoevalvacije (učitelji, samoevalvacijska skupina, udeleženci) seznanjeni $\mathrm{z}$ njenimi nameni in cilji. Ker izvajajo samoevalvacijo osebe, ki so laiki 
na tem področju, jih je potrebno najprej ustrezno usposobiti. Ob tem je potrebno izobraževanje oz. usposabljanje ponuditi poleg samoevalvacijski skupini celemu kolektivu. Samoevalvacija naj bi zajela domala vse zăposlene, saj lahko le s skupnimi močmi vseh zaposlenih dosežemo vidne rezultate na področju kakovosti dela. Analiza samoevalvacijskih procesov $v$ modelu POKI je pokazala, da so se usposabljali le člani samoevalvacijske skupine in ne tudi ostali zaposleni. To bi bilo potrebno $\mathrm{v}$ prihodnje popraviti, saj so bile nekatere osebe slabo informirane o poteku samoevalvacije. Poleg tega nekateri tudi niso vedeli, zakaj je samoevalvacija sploh potrebna in kaj samoevalvacijska skupina dela, saj se predhodno niso udeležili izobraževanja o samoevalvaciji in niso sodelovali pri njeni izvedbi (Zorić, 2003).

$\mathrm{V}$ nadaljevanju bomo primerjali model POKI z nekaterimi tujimi modeli, ki so se $\mathrm{v}$ zadnjih desetletjih uveljavili $\mathrm{v}$ svetu, in sicer $\mathrm{z}$ responzivno evalvacijo, participativno evalvacijo in evalvacijo z okrepitvijo moči. Skušali bomo ugotoviti, v kolikšni meri se model POKI približa tujim modelom, v čem se od njih razlikuje in kaj bi bilo potrebno izboljšati.

V responzivni evalvaciji (Stake, 1983) se izobraževalna organizacija pri evalvaciji programov usmerja predvsem $\mathrm{k}$ dejavnostim programa. Odziva se na predloge udeležencev izobraževanja in pri poročilu o uspešnosti programa upošteva tudi različne vrednote udeležencev. Ti elementi so $\mathrm{v}$ nekoliko drugačnih oblikah vidni tudi pri vpeljavi modela POKI. Tu evalvator upošteva predloge vseh udeležencev evalvacije (zaposlenih, vodstva, udeležencev izobraževanja, zunanjih partnerjev) in njihove različne vrednote. To pride do izraza predvsem na začetku, ko se na osnovi mnenja udeležencev evalvacije izobraževalna organizacija odloči, za katera področja znotraj modela POKI bo ugotavljala šibke točke. $\mathrm{V}$ ta namen izpolnijo udeleženci evalvacije anketni vprašalnik, v katerem podajo mnenje o delu predavateljev, organizaciji predavanj, kakovosti učnih gradiv, vsebinah izobraževanja, sodelovanju z zunanjimi partnerji ipd. Nato izobraževalna organizacija izbere nekaj področij modela POKI, ki so bila najslabše ocenjena oz. bi jih bilo potrebno po mnenju udeležencev evalvacije izboljšati. Izbirajo lahko med naslednjimi področji: doseganje ciljev, izobraževalni proces, udeleženci, učitelji, šola in partnerji ter vodenje in upravljanje.

Model evalvacije z okrepitvijo moči kot tudi model POKI temeljita na metodi notranje evalvacije, in sicer samoevalvaciji. Zato sta si modela podobna predusem $\mathrm{v}$ poteku samoevalvacije oz. vpeljavi modela v organizacijo. Znotraj evalvacije $z$ okrepitvijo moči je Fetterman (2001) razvil tri korake, s pomočjo katerih pomagamo udeležencem evalvacije, da se naučijo evalvirati izobraževalne programe; oblikovanje vizije izobraževalnih programov, ugotavljanje prednosti in slabosti izobraževalnega programa ter določitev ciljev in oblikovanje strategije za dosego teh ciljev izobraževalnega programa $v$ prihodnosti. Model POKI po drugi strani zajema korake, ki se nanašajo na delo institucije kot celote: odločitev za vpeljavo modela POKI, vzpostavitev samoevalvacijske skupine, oblikovanje vizije razvoja izobraževanja odraslih, zagotovitev potrebnih pogojev za delo, načrt informiranja zaposlenih ter akcijski načrt uvajanja izboljšav. Pri obeh modelih je skupno oblikovanje vizije razvoja kakovosti izobraževanja odraslih, kjer poudarjata, da jo morajo oblikovati vsi udeleženci evalvacije, od vodstva do ostalih zaposlenih ne glede na status. Delo znotraj obeh modelov je 
Da bi lahko dosegli visoko stopnjo aktivnosti udeležencev $v$ evalvaciji, jih je potrebno najprej usposobiti oz. jim razložiti procese evalvacije na njim razumljiv način. Easton (1996) tako poudarja, da so se udeleženci evalvacije sposobni naučiti procesov in postopkov evalvacije, le da jim moramo stvari predstaviti na njim razumljiv način. Udeležence je potrebno postopno uvajati $v$ terminologijo evalvacije, statistiěne postopke, uporabo metod ipd.

predvsem skupinsko, skupina pa je sestavljena zelo raznovrstno, tako da so zajeta mnenja vseh udeležencev evalvacije. Pri naslednjem koraku se pri obeh modelih udeleženci evalvacije odločijo, katere dejavnosti oz. področja so šibki in bi jih bilo potrebno izboljšati. Skupen pa je tudi načrt za prihodnost, kjer se udeleženci odločijo, katere akcije bodo potrebne, da bi se kakovost dela izboljšala. Ker oba modela temeljita na metodi samoevalvacije, opravljajo večino dela udeleženci (oblikujejo vizijo, ugotavljajo

\section{Za evalvacijo izo- braževanja odra- slih so potrebna številna nova} znanja. stanje organizacije, določijo cilje, ki jih nameravajo doseči s pomočjo modela, ipd.), evalvator pa je zgolj v vlogi svetovalca, usmerja delo skupine in jih spodbuja. Tako pridemo tudi do podobnosti modela POKI s participativno evalvacijo (Easton, 1996), ki prepušča osrednjo vlogo pri evalviranju dela izobraževalnih programov in institucij udeležencem evalvacije.

Tudi Fetterman (2001) znotraj evalvacije $\mathrm{z}$ okrepitvijo moči govori o demistifikaciji evalvacije, kar pomeni, da morajo udeleženci najprej pridobiti določena znanja o evalvaciji programov in lastnega dela, da bi lahko kasneje samostojno izvajali evalvacijo. V okviru modela POKI imajo udeleženci evalvacije (samoevalvacijska skupina) možnost izobraževanja o osnovah samoevalvacije, kazalnikih kakovosti, statistični obdelavi podatkov, timskem delu itd. S tem se model POKI še najbolj približa modelu evalvacije $\mathrm{z}$ okrepitvijo moči, saj skuša prav tako usposobiti udeležence evalvacije za kasnejše samostojno delo. Vendar so zaenkrat udeleženci evalvacije mnenja, da po dveh letih sodelovanja pri uvajanju modela POKI v izobraževalnih organizacijah še ne bi mogli samostojno izpeljati evalvacije. Polovica članov samoevalvacijske skupine meni, da bi potrebovali vsaj svetovalca za izvedbo evalvacije.

Ko govorimo o izobraževanju in usposabljanju za evalvacijo, se ob zgoraj opisanih podobnostih s tujimi modeli pojavi tudi razlika. In sicer so se pri vpeljevanju modela POKI v organizacije za izobraževanje odraslih imeli možnost izobraževati $O$ določenih temah $\mathrm{v}$ povezavi $\mathrm{z}$ evalvacijo le udeleženci $v$ okviru samoevalvacijske skupine, ki pa so bili predstavniki vodstva organizacije in nekateri zaposleni.

Nasprotno tuji modeli gledajo na to nekoliko Širše in nudijo možnost izobraževanja in vključevanja v evalvacijo tudi predstavnikom lokalne skupnosti, financerjem, delodajalcem, šiši javnosti ipd. V naslednji fazi vpeljevanja modela POKI bi bilo tako potrebno upoštevati napotke tujih modelov in ponuditi izobraževanje za evalvacijo vsem zainteresiranim skupinam.

Pri participativni evalvaciji in evalvaciji $\mathrm{z}$ okrepitvijo moči zelo izstopa temeljni cilj evalvacije. Easton (1996) nenehno poudarja, da je potrebno pri participativni evalvaciji opolnomočiti udeležence in jim omogočiti, da si pridobijo spretnosti in samozavest. Le tako bo njihova vloga pri usmerjanju njihove osebne in kolektivne usode dejavnejša. Fetterman (2001) pa za evalvacijo z okrepitvijo moči pravi, da je glavni namen pomagati ljudem, da si sami pomagajo, in izboljšati izobraževalne programe $\mathrm{z}$ uporabo samoevalvacije in refleksije. V modelu POKI je prav tako cilj opolnomočenje udeležencev 
evalvacije, le da ni tako poudarjen kot pri prejšnjih dveh.

V zvezi s tem je eden izmed temeljnih ciljev, ki naj bi ga dosegli z uporabo modela POKI, participativno odločanje o razvoju izobraževanja odraslih (Ponudimo odraslim kakovostno izobraževanje - interno gradivo, 2003). To pomeni, da bi o usodi izobraževanja odraslih znotraj izobraževalne organizacije odločali tudi ostali zaposleni in ne le vodstvo, seveda pod pogojem, da bi bili zaposleni usposobljeni za takšne odločitve. Tukaj pa nastopi vloga izobraževanja bodisi znotraj evalvacije bodisi je že sama evalvacija oblika izobraževanja, kot meni Easton (1996). Nadaljnja podobnost modela POKI s tujimi modeli evalvacije je $\mathrm{v}$ načinu komuniciranja med evalvatorjem in udeleženci evalvacije oz. interesnimi skupinami. Znotraj participativne evalvacije govori Easton (1996) o treh načinih komunikacije med evalvatorjem in interesnimi skupinami, in sicer o vertikalni (informacije prehajajo od nacionalnih institucij za izobraževanje odraslih do lokalnih institucij in obratno), horizontalni (udeleženci s podobnimi problemi se med seboj pogovarjajo, izmenjavajo mnenja ipd.) in eksterni komunikaciji (vključevanje čim več interesnih skupin - šritev mreže). Fetterman (2001) pa o evalvaciji z okrepitvijo moči pravi, da je dialog najpomembnejši del evalvacije $\mathrm{z}$ okrepitvijo moči, saj s pomočjo dialoga steče komunikacija med nadrejenimi in ostalimi zaposlenimi brez kakršnihkoli možnosti za sankcije. V modelu POKI je zajeta tako vertikalna komunikacija (Andragoški center Slovenije predstavlja nacionalno institucijo za izobraževanje odraslih, ki komunicira znotraj projekta POKI z lokalnimi institucijami za izobraževanje odraslih in obratno) kot tudi horizontalna komunikacija (med seboj komunicirajo zaposleni iz različnih izobraževalnih institucij, ki sodelujejo pri vpeljevanju modela POKI in se srečujejo s podobnimi problemi), ki ju predlaga Easton znotraj participativne evalvacije. Prav tako je prisoten tudi dialog, ki je pomemben del evalvacije $\mathrm{z}$ okrepitvijo moči.

Model POKI zajema dialog med zaposlenimi ter med zaposlenimi in njihovimi nadrejenimi. Vsi imajo pravico do svojega mnenja in so enakopravni člani samoevalvacijske skupine. Ponekod so vključili $v$ samoevalvacijo tudi zunanje par-
Glavni namen evalvacije z okrepitvijo moči je pomagati ljudem, da si sami pomagajo. therje in javno predstavitev rezultatov, kar se uvršča med eksterno komunikacijo znotraj participativne evalvacije.

Sklenemo Jahko, da ima model POKI kar nekaj podobnosti s tujimi modeli evalvacije glede poteka in izvedbe evalvacije. Č pa se osredotočimo na strukturo modela, lahko ugotovimo, da ima model POKI dokaj kompleksno strukturo v primerjavi z ostalimi modeli evalvacije. Model responzivne evalvacije (Stake, 1983) nima strogo določene strukture; evalvator si zastavi raziskovalne probleme, ko se seznani s programom evalvacije, deloma tudi v pogovorih s študenti, starši, z davkoplačevalci ipd. Nato problem raziskuje s pomočjo opazovanja in intervjujev. Evalvator se odziva na vnaprej zastavljene probleme in na tiste, ki se pojavljajo sproti. Da bi evalvator lažje prišel do odgovorov, oblikuje Stake ma-

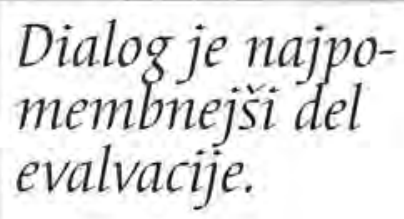
triko za vodenje evalvatorjevega dela. Model responzivne evalvacije je uporaben tako za formalne oblike izobraževanja kot tudi za neformalne. Participativna evalvacija (Easton, 1996) pa je v prvi vrsti namenjena neformalnim oblikam izobraževanja, saj je tam ključnega pomena, da zna udeleženec sam presoditi dobre in slabe lastnosti programov, kjer ni nikakršnega zagotovila za 
kakovost. Struktura modela je sestavljena iz odločitev o nalogah udeležencev oz. v kolikšni meri bodo ti aktivni, katero skupino bomo vključili $v$ evalvacijo (srednji menedžment, lokalno skupnost itd.) ter raven vprašanj, o katerih lahko udeleženci povedo svoje mnenje. Tukaj evalvatorje zanima predvsem, ali udeleženci lahko sprejemajo

\section{Pogoj za uspešno evalvacijo je tridi- menzionalen mo- del komuniciranja - vertikalno, horizon- talno in eksterno.}

odločitve le na lokalni ravni ali morebiti tudi na regionalni in nacionalni ravni. Pri evalvaciji z okrepitvijo moči (Fetterman, 2001) smo strukturo spoznali že prej, ko smo govorili o korakih, s pomočjo katerih se naučijo evalvirati izobraževalne programe. $\mathrm{Ti}$ so: oblikovanje vizije, presojanje prednosti in slabosti izobraževalnega programa ter oblikovanje strategije za dosego ciljev $v$ prihodnosti. Model evalvacije $\mathrm{z}$ okrepitvijo moči je uporaben za izobraževalne programe (tako formalne kot tudi neformalne), $\mathrm{z}$ določenimi prilagoditvami pa je uporaben tudi za posameznike, društva, organizacije ipd.

\section{$\checkmark$ Sloveniji potre- bujemo model za ugotarljanje kako- vosti izobraževanja odraslih, ki bo de- loval na sistemski ravni.}

$\mathrm{V}$ modelu POKI so področja razdeljena še na podpodročja in navedeni kazalniki kakovosti za vsako podpodročje (Ponudimo odraslim kakovostno izobraževanje - interno gradivo, 2003). To kaže na zelo kompleksno strukturo, če upoštevamo, da je model POKI oz. njegovo uvajanje namenjeno laikom. Če želi izobraževalna organizacija vpeljati celoten model POKI oz. zagotavljati kakovost na vseh področjih modela, je tako potrebno kar nekaj časa in motivacije za delo interesnih skupin, seveda poleg redne zaposlitve in ostalih obveznosti. Ob tem ne moremo mimo dejstva, da tudi po dveh letih
Model POKI ima natančno določeno strukturo z vsebinskimi področji, ki se nanašajo na kakovost dela organizacije za izobraževanje odrastih. Ta področja so:

- doseganje ciljev programa (v kolikšni meri izobraževalni program dosega zastavljene cilje)

- izobraževalni proces (kako se načrtuje in izpeljuje izobraževalni proces), udeleženci (kakovost dela z udeleženci), učitelji (aktivnosti učitelja ter profesionalni razvoj)

- šola in partnerji (odprtost v lokalna in širša okolja) ter

- vodenje in upravljanje (urejenost področja izobraževanja odraslih v izobraževalni organizaciji).

dela na vpeljevanju modela POKI v organizacije za izobraževanje odraslih udeleženci še vedno ne morejo samostojno izpeljati evalvacije. Prav tako tudi niso vpeljali celotnega modela POKI, temveč bodo $\mathrm{v}$ letošnjem šolskem letu (2003/2004) pričeli z izboljševanjem dela le na določenih področjih kakovosti.

\section{SKLEPNA MISEL}

Povečanje števila izobraževalnih ustanov in obsega izobraževalne ponudbe $\mathrm{v}$ izobraževalnih ustanovah za odrasle ter podrejenost izobraževanja trgu nas navaja, da bi ugotovili učinkovitost in druge kazalce kakovosti izobraževalnih programov za odrasle.

Če želimo vzpostaviti sistem ugotavljanja kakovosti, je potrebno gledati na izobraževanje odraslih celostno in izboljševati kakovost na več področjih. Da bi olajšali celostno vpeljevanje modela POKI $v$ organizacije za izobraževanje odraslih, bi bilo potrebno strukturo modela poenostaviti. 
Vsekakor je tudi v Sloveniji nujno potreben model za ugotavljanje kakovosti izobraževanja odraslih, ki bi deloval na sistemski ravni. Analiza o učinkih vpeljevanja modela POKI v izobraževalne organizacije (Zorić, 2003) je sicer pokazala, da zaposleni v izobraževalnih organizacijah menijo, da model POKI spodbuja skrb za kakovost izobraževanja odraslih v njihovi instituciji in do neke mere pozitivno učinkuje na razmišljanje zaposlenih o kakovosti njihovega dela. Vendar bi bilo potrebno $v$ primeru vzpostavitve sistema za ugotavljanje kakovosti izobraževanja odraslih vanj vključiti vse izvajalce izobraževanja, pri čemer ne bi smeli zanemariti neformalnih oblik izobraževanja. Poleg tega bi bilo potrebno določiti sistem razporejanja denarnih sredstev ter oblikovati kazalce kakovosti, ki bi bili merilo za ugotavljanje kakovosti. Model POKI sicer že ima opredeljene kazalce kakovosti, vendar ne omogočajo celostnega ugotavljanja kakovosti institucij, torej skupaj za vsa področja. Po dveh letih vpeljevanja modela POKI so tako izobraževalne institucije za določena področja $v$ okviru projekta POKI uspele ugotoviti, ali delajo kakovostno ali ne, še vedno pa ne vedo, kaj je s kakovostjo celotnega izobraževalnega programa in institucije. Potrebno je torej oblikovati celostno sliko o tem, kaj vse bi bilo potrebno izboljšati, da bi lahko rekli, da ponujajo kakovostne izobraževalne programe.

\section{LITERATURA}

Easton, P. A. (1996). Sharpening our tools: Improving evaluation in adult and nonformal education. Hamburg: UNESCO Institute for Education: German Foundation for International Development.

Fetterman, D. M. (2001). Foundations of empowerment eyaluation. Thousand Oaks, London, New Delhi: SAGE Publications.

Knox, A. B. (1989). Developing, administering and evaluating adult education. San Francisco, London:
Jossey-Bass Publishers.

Kovač, B. (1997). Kakovost v izobraževalni dejavnosti. Andragoška spoznanja, 3-4, str. 26-33.

Kump, S. (1995). Samoevalvacija v visokem §olstvu, Ljubljana: ACS.

Kump, S. (2000a). Konceptualni in metodološki pristopi v evalvaciji visokega šolstva, V Štrajn, D. (ur.): Evalvacija. Ljubljana: Pedagoški inštitut, str. 143-155.

Kump. S. (2000b). Paradigme, koncepti in metode $v$ evalvaciji izobraževanja. V S̆trajn, D. (ur.): Evalvacija. Ljubljana: Pedagoški inštitut, str. 13-25.

Macur, M. (1996). Evalvacija kulturne politike na podroçju gledališke dejavnosti. Magistrsko delo. Ljubljana: Univerzà v Ljubljani. Fakulteta za družbene vede.

Medveš, Z. (2000). Kakovost v šoli. Sodobna pedagogika, 4 , str. 8-27.

Možina, T. (2002). Evalvacija in razvoj izobraževalnih programov za odrasle. Magistrsko delo. Ljubljana: Univerza v Ljubljani. Filozofska fakulteta.

Musek-Lešnik, K., Bergant, K. (2001), Samoevalvacija v vzgojno-izobraževalnih organizacijah. Ljubljana: Inštitut za psihologijo osebnosti.

Ponudimo odraslim kakovostno izobraževanje - POKI: model za menedžment kakovosti izobraževanja odraslih na srednji šoli (interno gradivo). (2003). Ljubljana: ACS.

Sagadin, J. (1999). Programska evalyacija. Sodobna pedagogika, 2, str. 196-211.

Stake, R. E. (1983), Program evaluation, particularly responsive evaluation, V Madaus, G. F., ... (ur.). Evaluation models: Viewpoints on educational and human services evaluation. Boston, Dordrecht, Lancaster: Kluwer-Nijhof Publishing, str. 287-309.

Toivianinen, T. (2000). Sodobni razvoj kakovosti v izobraževanju odraslih na Finskem. Andragoška spoznanja, 4, str. 46-57.

Zoric, M. (2003). Učinki vpeljevanja samoevalvacijskega modela POKI $v$ organizacijah za izobraževanje odraslih. Diplomsko delo. Ljubljana: Univerza v Ljubljani. Filozofska fakulteta.

Wolf, R. M. (1996). Evaluation concepts and principles. V Tuijnman, A. C. (ur.). International encyclopedia of adult education and training, Oxford: Pergamon Press. str. 834-838. 
IV slovenskem prostoru ni moč najti enotnega prevoda za angleški izraz "empowerment". Mnogi ga prevajajo opolnomočenje, opolnomočiti nekoga, mu dati moč, okrepiti ga. Kar zadeva izraz "empowerment evaluation" se mi zdi še najboljši prevod "evalvacija z okrepitvijo moči", ki ga je deloma tudi uporabila Tanja Možina (2002). Zato bom v nadaljevanju govorila o evalvaciji z okrepitvijo moči, ko bom obravnavala Fettermanov model. 